\title{
Etyka zawodu detektywa w kontekście standardu minimalnego Internationale Kommission der Detektiv-Verbände
}

\section{Streszczenie}

Przedmiotem zainteresowania i dociekań naukowych podjętych przez autorów - prawników i licencjonowanych detektywów - stała się tytułowa etyka zawodu detektywa, wykonywanego także i przez nich, przy czym asumptem do podjęcia tematu w takim akurat, a nie innym brzmieniu były nie tylko ich doświadczenia zdobyte podczas orbitowania w świecie nauki i normatywizmu, lecz także - a może i przede wszystkim - wyniesione z obserwacji prowadzonej z perspektywy uczestników obrotu w realiach wykonywanego zawodu, obarczonego, niestety, także pewnymi niedoskonałościami.

Bazując na tych właśnie doświadczeniach i obserwacjach, punktem wyjścia uczyniono zdekodowanie znaczenia samego pojęcia etosu, przyjmując jednak w sposób twórczy i innowacyjny z perspektywy zapatrywań funkcjonujących $\mathrm{w}$ dotychczasowym piśmiennictwie - że na etos zawodu składa się jego elitaryzm i ekskluzywizm. Rozstrzygnięcia o etosie zawodu detektywa zapadać muszą w polu normatywnym wykreślonym przez ustawę z dnia 6 lipca 2001 r. o usługach de-

\footnotetext{
$1 \quad$ Mgr Marcin Berent - prawnik; asystent w Katedrze Prawa Karnego i Polityki Kryminalnej Wydziału Prawa i Administracji Uniwersytetu Mikołaja Kopernika w Toruniu; magistrant w Zakładzie Historii XX wieku Instytutu Historii i Archiwistyki Wydziału Nauk Historycznych tegoż Uniwersytetu; ekspert prawny w Kancelarii Radców Prawnych i Adwokatów „Lech Obara i Współpracownicy” w Olsztynie; licencjonowany detektyw w firmie EXPERTUS security-secret-services Group w Warszawie; konsultant prawny Polskiego Stowarzyszenia Licencjonowanych Detektywów (e-mail: mb@expertus.eu).

2 Dr Wiesław J. Modrakowski - dr nauk prawnych; licencjonowany detektyw i prokurent firmy EXPERTUS security-secret-services Group w Warszawie; Prezes Polskiego Stowarzyszenia Licencjonowanych Detektywów; Doradca ds. bezpieczeństwa oraz kontrwywiadowczej ochrony kontraktów i korporacji; b. oficer Biura ds. Przestępczości Gospodarczej Komendy Głównej Policji - nadkomisarz w st. spoczynku; b. Przewodniczący Zarządu Warszawskiego Polskiego Związku Pracodawców OCHRONA; członek wielu międzynarodowych organizacji bezpieczeństwa biznesu - w tym International Association of Auto Theft Investigators, World Association of Detectives International Police Association (e-mail:wjm@expertus.pl).
} 
tektywistycznych, tj. Dz.U. z 2002 r. Nr 12, poz. 110 ze zm. Egzegeza dogmatyczna jej uregulowań skłania do konkluzji, że zawód ten jest wprawdzie elitarny, choć nie bez zastrzeżeń w tym względzie, nie jest jednak ekskluzywny, co znajduje bezpośrednie przełożenie na zachodzące niekiedy w jego obrębie nieprawidłowości $w$ warstwie etycznej, a także moralnej, przy czym autorzy rozdzielają oba te pojęcia.

Powodów powyższego stanu rzeczy upatrują autorzy w niedostatkach warunkujących procedurę rekrutowania kandydatów do zawodu będącą rezultatem obniżenia standardów $\mathrm{w}$ tym względzie, a wynikającą z dokonania uwolnienia zawodu ustawą z dnia 13 czerwca 2013 r. o zmianie ustaw regulujących wykonywanie niektórych zawodów, tj. Dz.U. z 2013 r., poz. 829, wchodzącą w życie z dn. 1 stycznia 2014 r., postulując przy tym przywrócenie istniejących w tym względzie obostrzeń. Dostrzegają także niechęć władzy politycznej dla ewentualnego zwiększenia uprawnień przedstawicieli prywatnego sektora bezpieczeństwa, bez których utrudnione wydaje się pełne urzeczywistnienie roli społecznej, jaka przypada detektywom pełniącym wszakże zawód zaufania publicznego.

Autorzy nie tracą jednak z pola widzenia niezłej w sumie kondycji polskiej detektywistyki, która wyłania się z przeprowadzonych badań komparatystycznych, wykonanych na tle stanu ukształtowanego w innych państwach. Akcentują przy tym, że szanse stąd płynące - przynajmniej w jakimś zakresie - zauważone zostały przez Polskie Stowarzyszenie Licencjonowanych Detektywów - reprezentanta środowiska licencjonowanych detektywów z całej Polski, które przystąpiło do struktur tytułowej Internationale Kommission der Detektiv-Verbände - Międzynarodowej Federacji Prywatnych Stowarzyszeń Detektywów, w której zdobyć może nie tylko nowe doświadczenia, lecz także, wnosząc unikalny swój wkład, stać się europejskim liderem zdolnym do kreowania ponadnarodowych standardów samego zawodu, jak i wpisanych weń norm etycznych, konstruujących cały etos. Polskie Stowarzyszenie Licencjonowanych Detektywów ustanowiło także Kodeks Etyki Detektywa, który - co jednak niech nie zabrzmi nazbyt pretensjonalnie stawiany mógłby być za wzór tego typu legislacji rezonujący w przestrzeni polskiej detektywistyki jako takiej, zwłaszcza że na rodzimym rynku usług detektywistycznych nie ma swego konkurenta.

Słowa kluczowe: etos, etyka, elitaryzm, ekskluzywizm, kodeks etyczny, detektyw, detektywistyka, usługi detektywistyczne, kryminalistyka, deregulacja 


\title{
Detective's ethic in the context of Common Minimum Standards issued by International Federation of Associations of Private Detectives
}

\begin{abstract}
The authors - lawyers and licensed detectives - examine the topic of an ethic in detective's profession from theoretical and practical grounds. Although the authors are well positioned to delve into theoretical aspects of this topic, thanks to their strong academic background, the key input into the research is the practical experience they have gained while performing the profession; the profession they sadly acknowledge have some imperfections as well.

Based on their own experience and observations the starting point of their work is the study of detective's profession ethos. The angle of their examination is different to a traditional approach presented in other's publications available on the market. The authors, in an innovative and original way, claim that the detective's ethos is a result of profession's elitism and exclusivism. The profession's ethos has to be examined in the light of legal grounds in the Polish law system, the Act of 6 July 2001 on detective services (O.J. 2002 No. 12, Item 110, as farther amended). An extensive analysis of the act, brought a conclusion, that detective's profession is elite, although authors have noted that there are certain reservations on this thesis, however they have asserted that the profession is not exclusive, which is reflected in the instances of some ethic and moral violations, the topics they strictly separate.

The reason of the abovementioned shortcomings is not sufficiently stringent procedure of the profession's recruitment, which is a consequence of an easier access to the detective's license, granted by the Act of 13 June 2013 on deregulation of access to certain professions in Poland (O.J. 2013, Item 829), effective as of 1 January 2014. The authors call for restoration of previously existing restrictions with this regard. The authors notice as well that there is a politically-driven reluc-
\end{abstract}


tance to empower the representatives of the private security sector, hindering the fulfilment of a social role the detectives play as the agents of public trust.

The authors however do not omit in their work the acknowledgement of a good condition of polish detective sector which one can see in the comparative cross-country international examination. They point out to the benefits and opportunities stemming from this condition, partly noticed by The Polish Association of Licensed Private Investigators - the representative body of detectives in Poland, which not only became a member of The International Federation of Associations of Private Detectives but also adopted the Code of Detective's Ethics. The former is a unique opportunity to gain expertise from international community as well as to share its own experiences, perhaps become a European leader setting internationals standards and guidance for the detective profession; the latter, authors believe, should be perceived as the code of exemplary conduct, one which all detectives shall follow. It is worth to mention that the mentioned Code of Detective's Ethics is unique in its own nature on the Polish market as there is no other code encompassing the topic of detective's ethic.

Keywords: ethos, ethics, elitism, exclusivism, ethic code, detective, detective services, criminology, deregulation 


\section{Wprowadzenie (pojęcie ogólne etosu)}

Brzmienie tematu przedmiotowego tekstu obliguje w pierwszej kolejności do dokonania egzegezy semantycznej pojęcia „etos”, wszak jego zrelatywizowanie do zawodu detektywa przesądza o skonkretyzowanych implikacjach w płaszczyźnie tytułowej etyki jego wykonywania. Już nawet intuicyjne próby zdekodowania pojęcia etosu prowadzą do wniosku, że to pewien zbiór zasad (wartości) oraz norm i wzorów postępowania aprobowany i przyjmowany jako własny przez określoną zbiorowość. Taka intuicja znajduje potwierdzenie w definicjach słownikowych, przy czym z etosu wynikają określone wartości etyczne ${ }^{3}$.

Przyjmując nieco uproszczoną optykę, powiedzieć można, że etos konstruowany jest przez dwa elementy (a przynajmniej, w tradycyjnym ujęciu, elementy te na niego się składają lub go współtworzą), a to elitaryzm, rozumiany jako szczególna rola społeczna, która przypisywana jest danej grupie aprobującej i przyjmującej etos jako własny, oraz ekskluzywizm, rozumiany jako ograniczony dostęp do uzyskania statusu członka tej grupy. Tak pojmowany etos uprawniał dawniej do mówienia przede wszystkim o etosie rycerza ${ }^{4}$, współcześnie zaś - wymieniając jedynie przykładowo - o etosie żołnierza, prawnika, lekarza, architekta, a także - co najistotniejsze w tym miejscu - o etosie detektywa ${ }^{5}$. Wszystkie te zawody w mniejszym lub większym stopniu - pozostają zarówno elitarne, jak i ekskluzywne, z zastrzeżeniami co do zawodu detektywa, które doczekają się rozwinięcia w dalszej części niniejszego tekstu.

Mając na uwadze powyższe, nie można jednak mówić w sposób dowolny o etosie jakiejkolwiek grupy społecznej, czy - atomizując - grupy zawodowej, nie wszystkie one bowiem spełniają przyjęty przez autorów w niniejszym tekście wymóg elitaryzmu i ekskluzywizmu, który spełniony musi zostać łącznie. Przy takim ujęciu trudno byłoby zatem mówić o etosie murarza, tynkarza czy akrobaty,

3 Por. E. Sobol (red.), Mały stownik języka polskiego, Warszawa 1994, s. 189.

4 Szerzej na ten temat: G. Duby, Czasy katedr. Sztuka i społeczeństwo 980-1420, Warszawa 1984. Zob. też: M. Ossowska, Ethos rycerski i jego odmiany, Warszawa 2000. Por. L.S. Zakrzewski, Ethos rycerski w dawnej i wspótczesnej wojnie, Warszawa 2004.

5 Przyjmując założenie, że z etosu wynikają określone standardy etyczne obowiązujące daną grupę społeczną (zawężając: zawodową), to do klasycznych zawodów, w których mówić można o ich etosie, zalicza się współcześnie, prócz wymienionych, także zawód: nauczyciela, pracownika socjalnego, psychologa i księgowego. Tak przynajmniej: R. Tokarczyk, Etyka prawnicza, Warszawa 2005, s. 43. 
przypisanie któremuś z nich cechy elitarności i ekskluzywizmu budziłoby bowiem wątpliwości, co - oczywiście - nie umniejsza rangi tym grupom, zwłaszcza zaś nie dewaluuje społecznej ich doniosłości.

\section{Etos zawodu detektywa i jego elitaryzm oraz ekskluzywizm (rozwinięcie pojęcia ogólnego etosu)}

Intelektualnym jądrem niniejszej pracy stać ma się etos zawodu detektywa, co do którego przed momentem zgłoszono zastrzeżenia w zakresie uczynienia przez niego zadość wymogom elitaryzmu i ekskluzywizmu. Skoro tak, to sekwencja dalszych rozważań wprzód otwarta musi zostać rozstrzygnięciem w tym zakresie.

I tak odpowiedzi na pytanie o jego elitaryzm poszukiwać należy w polu normatywnym nakreślonym przez ustawę z dnia 6 lipca 2001 r. o usługach detektywistycznych ${ }^{6}$. Zgodnie $\mathrm{z}$ art. $2 \mathrm{UoUD}^{7}$ konstruującym definicję legalną dla pojęcia usług detektywistycznych, usługami tymi są czynności polegające na uzyskiwaniu, przetwarzaniu i przekazywaniu informacji o osobach, przedmiotach i zdarzeniach, realizowane na podstawie umowy zawartej ze zleceniodawcą, $\mathrm{w}$ formach i w zakresie niezastrzeżonym dla organów i instytucji państwowych na mocy odrębnych przepisów ${ }^{8}$.

Z samej już istoty usług detektywistycznych - jak się wydaje - wynika elitaryzm zawodu detektywa, albowiem ten pełni szczególną rolę społeczną ze względu

6 Dz.U. z 2002 r. Nr 12, poz. 110 ze zm.

$7 \quad$ Skrótem tym oznaczamy ustawę z dnia 6 lipca 2001 r. o usługach detektywistycznych, tj. Dz.U. z 2002 r. Nr 12, poz. 110 ze zm.

8 Tenże w brzmieniu: „Usługami detektywistycznymi są czynności polegające na uzyskiwaniu, przetwarzaniu i przekazywaniu informacji o osobach, przedmiotach i zdarzeniach, realizowane na podstawie umowy zawartej ze zleceniodawcą, w formach i w zakresach niezastrzeżonych dla organów i instytucji państwowych na mocy odrębnych przepisów, a w szczególności: 1) w sprawach wynikających ze stosunków prawnych dotyczących osób fizycznych; 2) w sprawach wynikających ze stosunków gospodarczych dotyczących: a) wykonania zobowiązań majątkowych, zdolności płatniczych lub wiarygodności w tych stosunkach, b) bezprawnego wykorzystywania nazw handlowych lub znaków towarowych, nieuczciwej konkurencji lub ujawnienia wiadomości stanowiących tajemnicę przedsiębiorstwa lub tajemnicę handlową; 3) sprawdzanie wiarygodności informacji dotyczących szkód zgłaszanych zakładom ubezpieczeniowym; 4) poszukiwanie osób zaginionych lub ukrywających się; 5) poszukiwanie mienia; 6) zbieranie informacji w sprawie, w której toczy się postępowanie karne, postępowanie w sprawach o przestępstwa skarbowe lub wykroczenia skarbowe albo inne, jeżeli w toku postępowania można zastosować przepisy prawa karnego. 2. Zleceniodawcą czynności, o których mowa w ust. 1 pkt 6, nie mogą być organy prowadzące lub nadzorujące postępowania w tych sprawach". 
na swe kompetencje (społeczne) ${ }^{9}$, które nie zostały zastrzeżone dla monopolu władzy państwowej, a które wymagają od niego odpowiednich kwalifikacji, predyspozycji i cech charakteru. Pierwszy warunek uzasadniający określenie zbioru zasad obowiązujących detektywów polskich mianem etosu zostaje zatem spełniony.

Rozstrzygnięcie w przedmiocie jego ekskluzywizmu dokonane winno zostać $\mathrm{w}$ oparciu o definicję zawartą w art. 4 ust. 2 UoUD, który expressis verbis stanowi, że detektywem jest osoba posiadająca licencję. Od strony formalnej wydawałoby się zatem, że kryterium ekskluzywizmu zawodowego detektywa jest spełnione. Ponieważ jednak nie wszystko, co formalnie realizuje znamiona określonego wymogu, czyni jemu zadość faktycznie, przeto poddać pod rozwagę trzeba jeszcze urealnienie praktyczne swoistego ograniczenia normatywnego w zakresie dostępu do zawodu detektywa. Urealnienie tego ograniczenia wynikać będzie z odpowiedzi na pytanie, kto może zostać detektywem, o tym zaś decyduje wpierw to, kto może ubiegać się o wydanie licencji. Ubiegać może się natomiast ten, kto: posiada obywatelstwo polskie (lub obywatelstwo innego państwa członkowskiego Unii Europejskiej lub przysługuje mu, na podstawie umów międzynarodowych lub przepisów prawa Unii Europejskiej, prawo do podjęcia zatrudnienia lub wykonywania działalności gospodarczej na terytorium Rzeczypospolitej Polskiej); ukończył 21 lat; posiada wykształcenie co najmniej średnie; ma pełną zdolność do czynności prawnych; nie toczy się przeciwko niemu postępowanie karne lub postępowanie w sprawach o przestępstwo skarbowe popełnione z winy umyślnej; nie był skazany prawomocnym wyrokiem sądu za przestępstwo lub przestępstwo skarbowe popełnione z winy umyślnej; nie został zwolniony dyscyplinarnie z Policji, Straży Granicznej, Agencji Bezpieczeństwa Wewnętrznego, Agencji Wywiadu, Biura Ochrony Rządu, wojska, prokuratury, sądu lub z innego urzędu administracji publicznej w Rzeczypospolitej Polskiej lub innym państwie w okresie ostatnich 5 lat; ma nienaganną opinię wydaną przez komendanta powiatowego (miejskiego) Policji właściwego ze względu na jego miejsce zamieszkania; posiada zdolność psychiczną do wykonywania czynności w zakresie usług detektywistycznych stwierdzoną orzeczeniem lekarskim; legitymuje się dokumentem potwierdzającym odbycie szkolenia w zakresie zagadnień ochrony danych osobowych, ochrony informacji

9 Sit venia verbo, można mieć uzasadnione wątpliwości, czy ze społecznymi kompetencjami, jakich wymaga się od detektywa, sprzężone zostały odpowiednie kompetencje normatywne (uprawnienia). Nie jest przedmiotem niniejszej pracy prezentowanie pogłębionych rozważań w tym względzie, wydaje się jednak, że - mimo autentycznych potrzeb - wątpliwość ta rozstrzygnięta musi zostać w sposób niezadowalający, przynajmniej dla reprezentantów profesji detektywistycznej. Zob. M. Berent, Analiza krytyczna ustawy o ustugach detektywistycznych w kontekście opracowania projektu nowej regulacji prawnej, http://www.psld.pl/wp-content/uploads/2016/01/Marcin_Berent_Zjazd_PSLD_Analiza_krytyczna_UoUD.pdf (13.02.2016). 
niejawnych, przepisów regulujących prawa i obowiązki detektywa oraz zasad wykonywania działalności gospodarczej w zakresie usług detektywistycznych ${ }^{10}$.

Powyższe wymogi warunkujące możliwość ubiegania się o wydanie licencji detektywa są konsekwencją deregulacji tego zawodu dokonanej przed trzema laty ${ }^{11}$. Prima facie wydawałoby się, że ilość tych wymogów jest znacząca, tym samym więc - wystarczająca. Takie założenie byłoby jednak wadliwe, a - przynajmniej - mylące, albowiem w ujęciu jakościowym zdają się one niedostateczne, jeśli zważy się na okoliczność, jakich dóbr w konsekwencji one dotyczą. W wymiarze praktycznym znacząco ograniczono zatem wymogi obowiązujące kandydatów do zawodu. Bez popadania w nadmierną frywolność intelektualną, nie sprowadzając jednakowoż problemu do absurdu, podjąć można próbę opracowania przykładowego profilu kandydata na detektywa polskiego w świetle obowiązujących aktualnie przepisów w tym względzie. Z profilu tego wynikać musiałoby, że kandydat ten ma być Polakiem (lub inną osobą, której przysługują odpowiednie uprawnienia stąd wynikające). Może być Polakiem młodocianym, wystarczy bowiem, aby ukończył 21 lat. Z zawodu może być wspomnianym już murarzem bądź tynkarzem, jeśli tylko posiada odpowiednie wykształcenie zawodowe w tym kierunku, będące wykształceniem średnim. Nic nie stoi na przeszkodzie temu, aby był np. hazardzistą, wszak to nie prowadzi - per se - do utraty pełnej zdolności do czynności prawnych. Kandydat ten może być także szalbierzem, gdyż szalbierstwo nie stanowi przestępstwa ${ }^{12}$, zatem w tej sprawie nie może toczyć się postępowanie karne. Przyszły ewentualnie detektyw może być także piratem drogowym, który niechcący potrącił śmiertelnie człowieka, gdyż przestępstwo tego typu nie jest przestępstwem umyślnym. Może też pozostawać - w razie wojny - przeznaczonym do ewakuacji razem ze starcami i z dziećmi, to wszak przesądza o tym, że być może nie miał nawet okazji do bycia zwolnionym w trybie dyscyplinarnym ze służb mundurowych. Kandydat ten może być także zatwardziałym pięknoduchem, posiadającym $z$ tego tytułu odpowiednie zdolności psychiczne, a także posiadać zdolność do bilokacji, byleby tylko formalnie odbył stosowne szkolenie. Jeśli na końcu wszystkie „wrażliwe” okoliczności uda mu się ukryć przed Policją dokonującą wywiadu środowiskowego (sit venia verbo, co nie wydaje się spektakularnym osiągnięciem), to kandydatowi takiemu droga do wykonywania zawodu detektywa zostaje otwarta.

$10 \quad$ Arg. $z$ art. 29 ust. 1 UoUD.

11 Zob. ustawę z dnia 13 czerwca 2013 r. o zmianie ustaw regulujących wykonywanie niektórych zawodów, tj. Dz.U. z 2013 r., poz. 829, która weszła w życie z dn. 1 stycznia 2014 r.

12 Arg. z art. 121 ustawy z dnia 20 maja 1971 r. - kodeks wykroczeń, tj. Dz.U. z 1971 r. Nr 12, poz. 114 ze zm. (dalej k.w.). 
Czy wobec powyższego zawód detektywa faktycznie uznać można za ekskluzywny? Wydaje się, że skłonić wypadałoby się ku odpowiedzi negatywnej, wszak detektywem zostać może w zasadzie niemal każdy ${ }^{13}$ (co oczywiście nie oznacza, że po uwolnieniu zawodu nie ma pośród "nowych" detektywów profesjonalistów w najlepszym znaczeniu tego słowa, nie ma bowiem wątpliwości, że większość z nich z pewnością za takowych może być uznana), argument zaś - pojawiający się zresztą niezwykle często przy tego typu okazjach - że wolny rynek wyeliminuje najsłabsze podmioty, nie znalazł, niestety, odzwierciedlenia w rzeczywistości. Odzwierciedlenie $\mathrm{w}$ rzeczywistości znajduje natomiast stosunkowo niska ocena społeczna zawodu detektywa ${ }^{14}$, nad czym należy nie tylko ubolewać, lecz także - a może i przede wszystkim - przedsięwziąć określone działania. Co ważne, acz niekoniecznie zaskakujące, zarys badań nad stanem polskiej detektywistyki uzasadnia przekonanie o braku realnej perspektywy, przez pryzmat której prowadzona mogłaby być rzetelna ocena zawodu detektywa. Pośród źródeł wiedzy o polskiej detektywistyce z trudem znaleźć można te, które stać by się mogły pożądaną płaszczyzną społecznej obserwacji rzeczywistej pracy polskiego detektywa i realnej jego istoty. $Z$ doniesień medialnych wyłania się nierzadko jego obraz jako oszusta, naciągacza, hochsztaplera, kuglarza czy dowodowego fabrykanta ${ }^{15}$. Cóż z tego, że kreatorem takiego wizerunku są pozycje piśmiennicze o zredukowanych ambicjach intelektualnych, jeśli to właśnie one najmocniej rezonują w sferze społecznej wymownym i sugestywnym często przekazem, na który "pracują” nieliczni, a „płacą” wszyscy przedstawiciele zawodu. Filmy fabularne natomiast zdają się raczej nie budzić żadnych skojarzeń z polskim detektywem, zaś dokumentalizowane seriale w tym względzie nierzadko odbierane są przez ich widzów bez należytej estymy, za to z przesadną deprecjacją powagi zawodu. Jedynym właściwie rzetelnym źródłem wiedzy o polskiej detektywistyce jest kształcenie uniwersyteckie, jednak - ze względu na ograniczony jego zasięg - nie jest ono zdolne do przedstawienia

13 Zob. wypowiedź W.J. Modrakowskiego dla mediów: A. Jankowska, Wolny jak detektyww „"Wprost” 4.01.2015, s. 45 i nast.

14 Niska ocena społeczna w tym względzie zdaje się rozciągać na cały sektor prywatnych służb ochrony w Polsce, detektywi zatem nie cieszą się złą sławą w odosobnieniu, trafnie zaś konstatuje (choć konstatacja to niewesoła) B. Hołyst: „W opinii społecznej oraz w mediach obraz prywatnych służb ochrony w związku z licznymi nadużyciami (podkr. nasze - M.B., W.J.M.), przekroczeniami kompetencji tych służb, jest raczej negatywny". Tak: idem, Kryminalistyka, Warszawa 2007, s. 1333.

15 Autorzy niniejszego tekstu celowo rezygnują w tym miejscu z przywołania odpowiednich relacji prasowych czy radiowych, te bowiem - pozwalając na personalną identyfikację konkretnych osób - mogłyby być dla nich nazbyt obraźliwe, na co nie ma miejsca w opracowaniach o charakterze naukowym, a do takiego aspiruje przedmiotowy artykuł. Autorzy czują się jednak zwolnieni z tego obowiązku, gdyż informacje te są powszechnie dostępne, wiadomo też, jakie czasopisma przodują w ich kolportażu. 
prawdziwego obrazu dokumentującego rzeczywiste warunki wykonywania zawodu detektywa ogółowi społeczeństwa, niezainteresowanego zresztą w swej większości poznaniem niuansów w obraz ten się wpisujących. Kształcenie to ma ograniczoną doniosłość także ze względu na brak w zasadzie systemowego kształcenia akademickiego, detektywistyka bowiem - jako materia wykładowa-czerpie najmocniej swą siłę z podstaw kryminalistyki, której, odnotowując na marginesie, niestety, w realiach polskich uniwersytetów nierzadko nie poświęca się należytej uwagi, zwłaszcza zaś czasu wyznaczanego programem nauczania, co w konsekwencji nie przynosi pożądanych i wymiernych dla ujęcia praktycznego efektów ${ }^{16}$.

Bacząc na powyższe, nie ma, znów: niestety, alternatywy dla udzielenia negatywnej odpowiedzi na pytanie, czy zawód detektywa jest ekskluzywny, mimo bowiem formalnych kryteriów stawianych kandydatom na detektywa w rzeczywistości nie stwarzają one dostatecznej zapory chroniącej dostępu do wykonywania zawodu, przynajmniej nie na tyle, aby można było mówić o jego ekskluzywizmie - to bardziej normatywna iluzja, aniżeli realna soczewka mająca skupiać pożądane cechy poszczególnych kandydatów.

Czy zawód detektywa był zatem kiedyś ekskluzywny? Wydaje się, że tak. Ograniczone ramy objętościowe niniejszego tekstu nie pozwalają na formułowanie jakichś obszerniejszych postulatów w płaszczyźnie lex ferenda, dość zatem powiedzieć, że obowiązujący przed deregulacją kandydatów na detektywa państwowy egzamin licencyjny z zakresu znajomości przepisów Konstytucji RP ${ }^{17}$, przepisów dotyczących Policji, nieistniejącego już Urzędu Ochrony Państwa, Straży Granicznej, ochrony danych osobowych, ochrony informacji niejawnych oraz przepisów prawa cywilnego i karnego (materialnego i procesowego), kryminalistyki, krymi-

16 Badania nad stanem polskiego piśmiennictwa przedmiotu wykazują, że pośród nielicznej literatury poświęconej detektywistyce par excellence wymienić można w zasadzie tylko: T.R. Aleksandrowicz (red.), Komentarz do ustawy o ustugach detektywistycznych, Warszawa 2002, częściowo zresztą i tak już zdezaktualizowany; bazujące w pewnej mierze na tym komentarzu: T.R. Aleksandrowicz, J. Konieczny i A. Konik, Podstawy detektywistyki. Ustugi detektywistyczne, prawo, taktyka, moralność, Warszawa 2008 oraz: G. Gozdór, Ustugi detektywistyczne, Warszawa 2005. W akademickiej literaturze stricte kryminalistycznej nie poświęcono osobnego rozdziału problematyce detektywistycznej-por. M. Kulicki, V. Kwiatkowska-Wójcikiewicz, L. Stępka, Kryminalistyka. Wybrane zagadnienia teorii i praktyki śledczo-sq̨dowej, Toruń 2009; T. Hanausek, Kryminalistyka. Zarys wykładu, Warszawa 2009; J. Widacki (red.), Kryminalistyka, Warszawa 2012; J. Kasprzak, B. Młodziejowski, W. Brzęk, J. Moszczyński, Kryminalistyka, Warszawa 2006; G. Kędzierska, W. Kędzierski, Kryminalistyka. Wybrane zagadnienia techniki, Szczytno 2011. Pewnym wyjątkiem na tym tle jest podręcznik B. Hołysta, jednak nawet tam, pomimo jego objętości, zwłaszcza zaś uwzględnienia pośród jego treści rozdziału zatytułowanego „Rola prywatnych służb ochrony w zapobieganiu przestępczości”, a także pozycji piśmienniczych poświęconych detektywistyce w literaturze uzupełniającej umieszonej przy końcu rozdz. LXII, brak jest w zasadzie wiadomości nt. problemów detektywistyki jako takiej. Zob. idem, op. cit., s. 1321-1335, zwł. s. 1332-1334.

17 Dz.U. z 1997 r. Nr 13, poz. 94 ze zm., sprost. Dz.U. z 2001 r. Nr 28, poz. 319. 
nologii i wiktymologii oraz psychologii sądowej pozwalał na doskonalsze prowadzenie ich selekcji i - w ostatecznym rozrachunku - dobór najlepszych z nich do wykonywania zawodu - summa summarum - zaufania publicznego.

\section{Etyka zawodu detektywa a dostęp do niego (zarys postulatów w płaszczyźnie lex ferenda)}

W kontekście wcześniejszych rozważań, skoro o etosie zawodu, a w ślad za nim o etycznych aspektach jego wykonywania, decyduje sposób naboru nowych reprezentantów gwarantujący napływ najlepszych kandydatów, przeto od kryteriów tego doboru wszystko w tym względzie zależy. Jednocześnie obecne wymogi formalne, po spełnieniu których uzyskać można status detektywa, zdają się być niewystarczające, $\mathrm{w}$ ostatecznym rozrachunku poddając pod wątpliwość cały etos i wynikające z niego względy etyczne. W pełni zatem podzielić można postulaty zaprezentowane przez Polskie Stowarzyszenie Licencjonowanych Detektywów ${ }^{18}$ w zakresie warunków uzyskania licencji detektywistycznej.

I tak, pośród tych postulatów wymienić wypada w pierwszej kolejności możliwość uzyskania licencji wprawdzie na nowych (tj. po deregulacji) warunkach, zatem bez konieczności składania egzaminu, lecz ze zobowiązaniem kandydata do uczestnictwa we właściwym szkoleniu, przy czym tak uproszczony tryb dotyczyć miałby wyłącznie osób legitymujących się wykształceniem prawniczym bądź administracyjnym lub osób uprzednio już wykonujących czynności detektywistyczne w rozumieniu art. 2 ust. 1 UoUD. W przypadku osób, które wykształcenia takowego by nie posiadały lub też wcześniej nie wykonywały czynności detektywistycznych w rozumieniu przywołanego artykułu, przywrócony winien zostać egzamin licencyjny. Godne aprobaty jest także stanowisko Polskiego Stowarzyszenia Licencjonowanych Detektywów, zgodnie z którym osoby już posiadające stosowną licencję miałyby zostać uprawnione do zatrudniania pracowników w charakterze asystenta detektywa, który swe czynności wykonywałby pod nadzorem i w ramach kompetencji licencjonowanego detektywa (i na jego odpowiedzialność?). Osoba taka miałaby spełniać wymogi wynikające z właściwej w tym względzie ustawy i uzyskać wpis do rejestru pracowników prowadzonego przez agencję (lub innego odpowiedniego w tym zakresie). Słusznie przy tej okazji podnosi się, że byłaby to znakomita okazja do zdobycia niezbędnego doświadczenia i utwierdzenia się w przekonaniu o dokonaniu trafnego wyboru zawodowego. W końcu też zasadnie postuluje się, aby zabronić wszelkim podmiotom funkcjo-

18 O samym Stowarzyszeniu Licencjonowanych Detektywów mowa będzie w dalszej części tekstu. 
nowania na rynku pod nazwą mogącą wprowadzać w błąd co do zakresu świadczonych usług o charakterze detektywistycznym, jeśli prowadzące je osoby nie posiadałyby koniecznej w tym przypadku licencji detektywistycznej, zabieg takowy jest bowiem nie tyle nieetyczny, co oszukańczy ${ }^{19}$.

Powyższemu rozumowaniu postawić można by zarzut „korporacyjności” zawodu i chęci niczym nieuzasadnionego blokowania dostępu do niego potencjalnie nowym doń kandydatom. Zarzut takowy byłby jednak błędny i nieznajdujący umocowania w nowych realiach po deregulacji. Ratio legis jej dokonania - przynajmniej w postulatach teorii - ogniskowało się w deklarowanej potrzebie podniesienia jakości usług detektywistycznych oraz obniżenia ich cen. Jakkolwiek nie ulega wątpliwości, że wielu spośród detektywów zrekrutowanych po deregulacji to niekwestionowani profesjonaliści, to jednak z badania środowiskowego wyłania się obraz rzeczywistości innej aniżeli deklarowanej w przywołanych powyżej postulatach teorii, a mianowicie: zamiast podniesienia jakości rynku usług detektywistycznych doprowadzono do częściowego jej obniżenia, natomiast zamiast obniżenia cen profesjonalnych usług detektywistycznych dał się zaobserwować trend przeciwny. Wydaje się, że jednak chociażby korporacyjny, jeśli już nie państwowy, egzamin z zakresu wiedzy prawno-kryminalistyczno-kryminologicznej oraz statusu prawnego detektywa i przedsiębiorcy przyczyniłby się do minimalnej selekcji kandydatów do wykonywania usług, stanowiąc gwarancję ochrony podstawowych praw i wolności obywatelskich, a także swobody działalności gospodarczej, które wprawdzie są chronione (autorzy tego nie kwestionują), wydaje się jednak, że w stopniu nie w pełni zadowalającym.

Oficjalnie uwolnienie zawodu detektywa odbywało się pod sztandarem urzeczywistnienia wspomnianej przed momentem wolności gospodarczej, trudno jednak było (i chyba nadal jest) oprzeć się wrażeniu, że w istocie powodem faktycznym dla jego przeprowadzenia była - przynajmniej w jakiejś mierze - niemoc państwa wobec lawinowo wzrastającej przestępczości, która - w ogólnym trendzie - maleć zaczęła dopiero od roku $2006^{20}$. Wydaje się jednak, że gdyby deklaracja oficjalna byłaby prawdziwa, wówczas państwo zapewniłoby realne uprawnienia reprezentantom sektora prywatnego. Zamiast tego wypreparowano normatywny fantom stwarzający iluzję wolności gospodarczej, państwo zaś uwolniło się od części podstawowych swoich obowiązków. Symptomatyczne przy tym jest to, że - jak wynika z danych zebranych przez Polskie Stowarzyszenie Licencjonowanych Detektywów - połowa biur detektywistycznych i praktykujących prywatnych

\footnotetext{
19 Tak: http://www.licencjonowanidetektywi.pl/dla-mediow (13.02.2016).

20 Por. http://statystyka.policja.pl/st/ogolne-statystyki/47682,Postepowania-wszczete-przestepstwa-st wierdzone-i-wykrywalnosc-w-latach-1999-2014.html (13.02.2016).
} 
detektywów zorganizowała się w ostatnim 1,5 roku, podczas gdy pierwsza połowa potrzebowała na to ćwierć wieku (1989-2014), a dysproporcja ta - w świetle najnowszych danych - stale się pogłębia, niejednokrotnie ze szkodą dotykającą przede wszystkim beneficjentów (klientów) usług detektywistycznych, a także dla samego etosu zawodowego.

\section{Stan polskiej detektywistyki w ujęciu komparatystycznym}

Powyższe refleksje napawać mogą smutkiem potęgowanym poczuciem traconych stale szans dla uczynienia z polskiej detektywistyki lidera zdolnego do kreowania standardów zawodowych pośród przedstawicieli zawodu w innych państwach, w tym zwłaszcza standardów etycznych budujących cały etos. Analiza komparatystyczna w zakresie stanu polskiej detektywistyki dokonywana na tle wybranych państw europejskich wskazuje, że jej kondycja i tak wypada jednak znacznie powyżej średniej europejskiej, co obrazuje poniższa tabela 1.

Tabela 1. Polska detektywistyka w ujęciu komparatystycznym na tle wybranych państw europejskich

\begin{tabular}{|c|c|c|c|c|c|c|c|c|c|c|c|c|}
\hline & $\frac{\frac{\pi}{0}}{\frac{\pi}{0}}$ & $\begin{array}{l}\frac{\pi}{\sigma} \\
\frac{\pi}{\pi} \\
\frac{\pi}{4} \\
\end{array}$ & 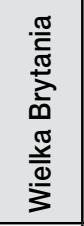 & 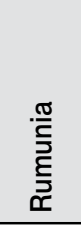 & $\begin{array}{l}\frac{\pi}{2} \\
\frac{0}{0} \\
\vdots \\
\text { ஸे } \\
\end{array}$ & $\begin{array}{l}\text { ते } \\
\text { o } \\
\text { ì }\end{array}$ & 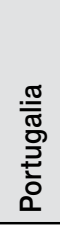 & 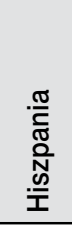 & $\begin{array}{l}\frac{\pi}{\pi} \\
\frac{\pi}{5} \\
\end{array}$ & 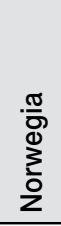 & $\begin{array}{l}\frac{\pi}{0} \\
\frac{\pi}{\frac{\pi}{5}} \\
\frac{5}{i}\end{array}$ & $\frac{\frac{\pi}{N}}{\frac{N}{2}}$ \\
\hline $\begin{array}{l}\text { Liczba prywatnych } \\
\text { biur } \\
\text { detektywistycznych }\end{array}$ & 950 & 300 & 2000 & 670 & 81 & 3000 & 20 & 600 & 7 & 50 & 23 & 28 \\
\hline $\begin{array}{l}\text { Liczba } \\
\text { praktykujących } \\
\text { prywatnych } \\
\text { detektywów }\end{array}$ & 1547 & 750 & 3000 & 2000 & 95 & 3000 & 50 & 2000 & 37 & 120 & 40 & 75 \\
\hline $\begin{array}{l}\text { Regulacja prawna } \\
\text { działalności }\end{array}$ & tak & tak & nie & tak & tak & tak & nie & tak & nie & nie & tak & nie \\
\hline Licencja & tak & tak & nie & tak & tak & tak & nie & tak & nie & nie & tak & nie \\
\hline Kontrola działalności & tak & tak & nie & tak & tak & tak & nie & tak & tak & nie & tak & nie \\
\hline $\begin{array}{l}\text { Raport } \\
\text { detektywistyczny } \\
\text { jako dowód w sądzie }\end{array}$ & tak & tak & nie & tak & tak & tak & nie & tak & tak & tak & tak & nie \\
\hline
\end{tabular}

Źródło: opracowanie własne na podstawie danych zebranych w dn. 15-18 kwietnia 2015 roku podczas kongresu IKD w Barcelonie. 


\section{Polskie Stowarzyszenie Licencjonowanych Detektywów w strukturach Internationale Kommission der Detektiv-Verbände (uwagi na tle Kodeksu Etyki Detektywa Polskiego Stowarzyszenia Licencjonowanych Detektywów)}

Wyłaniająca się z zaprezentowanego powyżej zestawienia szansa zauważona została przez wspominane już wcześniej w niniejszym tekście Polskie Stowarzyszenie Licencjonowanych Detektywów - reprezentanta środowiska licencjonowanych detektywó $\mathrm{w}^{21} \mathrm{z}$ całej Polski, które powołane zostało pod koniec 2008 roku, pełnoprawnym podmiotem prawnym stając się w roku kolejnym. Koncepcja tkwiąca u podstaw powołania do życia Polskiego Stowarzyszenia Licencjonowanych Detektywów zrodzić miała się pod wpływem przekonania, że o losach środowiska polskich detektywów decydować nie mogą wyłącznie osoby spoza tego środowiska, a zatem takie, które nie wykonują zawodu detektywa, nie mając odpowiednich uprawnień w tym względzie oraz prawa do prowadzenia działalności gospodarczej w zakresie usług detektywistycznych ${ }^{22}$. Szczególnego podkreślenia wymaga fakt, że Polskie Stowarzyszenie Licencjonowanych Detektywów jest jedynym w kraju zrzeszeniem osób fizycznych posiadających tytuł zawodowy detektywa otrzymany na podstawie licencji. Aktywność Polskiego Stowarzyszenia Licencjonowanych Detektywów zogniskowana została w staraniach zmierzających do podniesienia jakości usług detektywistycznych oraz przestrzegania zasad etyki zawodowej podczas wykonywania przyjętych zadań. Co szczególnie istotne, aktywność ta stała się - zgodnie z potwierdzoną w praktyce deklaracją samego Stowarzyszenia - „wyznacznikiem przyjęcia w orzecznictwie sądów określenia Stowarzyszenia jako jedynego reprezentanta detektywistycznej grupy zawodowej w Polsce"23.

Jedną z pierwszych inicjatyw podjętych przez władze Polskiego Stowarzyszenia Licencjonowanych Detektywów było uchwalenie Kodeksu Etyki Detektywa stanowiącego zbiór zasad i reguł etycznych, którymi kierować winien się detektyw należący do Stowarzyszenia, przy czym zalecono poszanowanie jego uregulowań przez każdego detektywa wykonującego zawód w Polsce. Kodeks Etyki Detektywa Polskiego Stowarzyszenia Licencjonowanych Detektywów, jak każdy zresztą

21 Autorzy nadmiernie być może eksploatują pojęcie detektywa „licencjonowanego", wszak innego nie ma, nie można być bowiem detektywem nielicencjonowanym. Autorzy pragną jednak w ten sposób wyeksponować fakt istnienia tejże licencji (wraz z niedomaganiami systemowymi w zakresie kryteriów jej zdobycia), nie mają przeto poczucia, aby czynili to ze szkodą dla przejrzystości swych rozważań.

22 Zob. http://www.licencjonowanidetektywi.pl/ (13.02.2016).

23 Ibidem. 
kodeks etyczny, stanowi źródło prawa obowiązującego wszystkich członków dobrowolnie zrzeszonych w strukturach Stowarzyszenia w zakresie norm postępowania w płaszczyźnie deontologii zawodowej. Stał się on nie tylko determinantą postępowania dla adresatów jego norm, ale także przedmiotem zainteresowania przedstawicieli polskiej nauki prawa karnego, również dlatego, że zawarte w nim normy dyscyplinarne zaliczone zostały przez rodzime orzecznictwo do kategorii prawa represyjnego. Kodeks Etyki Detektywa Polskiego Stowarzyszenia Licencjonowanych Detektywów jest unikalny także z innych powodów, którym - ze względu na brzmienie tematu niniejszej pracy i wynikającego z niego kierunku intelektualnej jej osnowy - poświęcić wypada nieco jeszcze uwagi, zwłaszcza że problematyka kodeksów etyki zawodowej zajmuje centralne miejsce pośród rozważań o etyce zawodowej jako takiej.

Stosownie do powyższego założenia wprzód powiedzieć trzeba, że nie każdy zbiór norm etyki zawodowej aspirować może do miana kodeksu tejże etyki. Normy konstruujące kodeks tego typu znajdują bowiem swe zakotwiczenie w pewnej aksjologii zabarwionej moralnym stymulatorem ich powstania. Tym samym zbiór norm niemotywowany względami etycznymi stać się może co najwyżej swoistym - jakby powiedzieli to Niemcy - Prozessordnung lub - przy uwzględnieniu pewnego pensum moralności - Praxisordnung. Same techniczne normy wyznaczające określone kierunki działania to za mało, orbitując w tej poetyce semantycznej kodeks taki stać się bowiem musi innerer Halt, wówczas dopiero staje się kodeksem etycznym w pełnym znaczeniu tego słowa. Równolegle stracić z pola widzenia nie można faktu, że samo ustanowienie tego typu kodeksu bez jednoczesnego ukonstytuowania środków jego przestrzegania nie jest wystarczającym gwarantem urzeczywistnienia konstruujących go norm. Co więcej, takie jego ujęcie może stać się przyczyną powstania cynizmu moralnego i bałwochwalczego samozadowolenia zawodowego wynikającego z bezzasadnego przekonania, że samo ustanowienie jakiegokolwiek kodeksu czyni zadość wszelkim wymogom w tym zakresie. Wobec tego pierwszorzędna rola determinująca pożądany kształt kodeksu etyki zawodowej przypada faktycznym powodom jego powstania. Wiele spośród tych przyczyn pozostaje w immanentnym związku z edukacją oraz swoistym wymuszeniem moralnej poprawności w obrębie danego zawodu i - w konsekwencji - zapobieganiem podejmowaniu zachowań niepożądanych. Dobrze i transparentnie ukształtowany kodeks etyki zawodowej stać się może istotnym źródłem edukacyjnym poprzez wyznaczanie standardów wskazujących na to, co w zawodzie stanowi dobro moralne, a co zawodowe zło. Już sama świadomość istnienia takich normatywnych drogowskazów jest niezawodnym niekiedy stymulatorem pożądanych zachowań, odrzucanych także w obawie przed reakcją środowiska zawodowego będącego punktem odniesienia dla ewentualnego naruszyciela ustanowionych 
norm kodeksowych. Tak opisana sankcja rozsiana, bacząc na widoczny i postępujący rozkład więzi społecznych (choć bez popadania w nadmierną histerię w tym względzie), bywa niekiedy niewystarczająca, finalnie więc - zawodna. Dlatego też dobre kodeksy etyki zawodowej winny przewidywać sankcję o charakterze represji zindywidualizowanej, grożącej członkom społeczności związanej jego postanowieniami, jak np. wydalenie $z$ danej grupy, której etos postępowania został naruszony. Warto jeszcze dodać, że pośród przyczyn ustanawiania kodeksów etyki zawodowej tkwić mogą różnorakie przesłanki: od altruistycznych przekonań (wartościowanych dodatnio) do egoistycznego cynizmu moralnego (wartościowanego ujemnie), który stać mógłby się parawanem skrywającym korporację zawodową przed niekorzystną oceną moralną postępowania jego członków. Nie ma zatem wątpliwości -zwłaszcza z perspektywy socjologicznej-że kodeks etyki zawodowej winien opierać się na wspólnej aksjologii i spójnym systemie wartości reprezentowanych i internalizowanych przez ogół członków tworzących grupę, odartych jednak z motywacji umocowanej w arywizmie ${ }^{24}$.

Wszystkim powyższym a pożądanym wymogom czyni zadość Kodeks Etyki Detektywa przyjęty przez Polskie Stowarzyszenie Licencjonowanych Detektywów, będąc przy tym - jak się przynajmniej wydaje - wolnym od opisanych zagrożeńn ${ }^{25}$.

Urzeczywistnieniem ambicji zaistnienia reprezentantów polskiej detektywistyki w obrocie na szczeblu europejskim było także przyjęcie Polskiego Stowarzyszenia Licencjonowanych Detektywów w poczet członków tytułowej Internationale Kommission der Detektiv-Verbände (IKD) podczas kongresu w Barcelonie zorganizowanego w kwietniu 2015 roku.

IKD to założona w 1964 roku międzynarodowa parasolka składająca się z prywatnych stowarzyszeń detektywów i - pierwotnie - także usług ochroniarskich na całym świecie, której podstawowym celem jest wyznaczanie i przekazywanie zatwierdzonego przez IKD poziomu dotyczącego śledztw w sektorze prywatnym jako wymagalnego standardu minimalnego w Unii Europejskiej. Wskazanej federacji przypada niebagatelna rola na rynku usług detektywistycznych ze względu na nieobecność zharmonizowanych regulacji na liberalnym, międzynarodowym wolnym rynku, która stwarza niepewność, nieuczciwą konkurencję i atrakcje do złych metod wykonywania usług.

Badania prowadzone przez IKD ujawniły brak jednolitego, powszechnego standardu w 22 państwach (Austria, Belgia, Dania, Czechy, Niemcy, Francja, Grecja, Węgry, Irlandia, Włochy, Łotwa, Litwa, Luksemburg, Holandia, Norwegia, Polska, Portugalia, Szwecja, Słowacja, Słowenia, Hiszpania i Wielka Brytania), brak legi-

\footnotetext{
24 Zob. R. Tokarczyk, op. cit., s. 60.

25 Tenże opublikowany na stronie: http://www.psld.pl/o-psld/kodeks-etyki-detektywa/ (13.02.2016).
} 
slacji w tym zakresie, różne procedury, różnice w kryteriach i niezgodną z ustawodawstwem tolerancję przestępstw.

Czyniąc punktem wyjścia założenie o niemożliwości dalszego utrzymywania tego stanu rzeczy, IKD zaproponowała, aby na minimalny standard wymagań osób wykonujących zawód prywatnego detektywa składały się przede wszystkim:

$\square$ osobiste wymagania, a to: minimalny wiek i zdolność psychiczna - Opcja 1.;

$\square$ uczciwość, a to: czysta kartoteka kryminalna - Opcja 2.;

$\square$ kompetencja, a to: sprawdzanie testem posiadanej wiedzy, praktyki i doświadczenia - Opcja 3.;

$\square$ minimalne odszkodowanie, a to: profesjonalna kompensacja na poziomie $100000 €$ - Opcja 4.;

- kodeks etyczny, a to: obowiązujący kodeks IKD z obligacjami utrzymania w tajemnicy informacji - Opcja 5.

Wyjątki od Opcji od 1 do 5 miałyby być stosowane przez krajowy organ licencjonowania, natomiast ważność opcji liczona od daty przystąpienia do IKD.

\section{Rekapitulacja}

Tytułem rekapitulacji powyższych rozważań powiedzieć wypada, że - mimo usprawiedliwionych i zasługujących na pełne urzeczywistnienie ambicji przedstawicieli środowiska - zawód detektywa w Polsce, w swej elitarności, nie jest, niestety, ekskluzywny, jego etos - przynajmniej w najlepszym i najpełniejszym znaczeniu tego słowa - jest zatem lokowany bardziej w sferze ewentualnych pragnień i wyobrażeń, aniżeli w polu okoliczności faktycznie istniejących. Słuszność takiego twierdzenia determinowana jest przez wadliwe, a co najmniej pozostawiające sporo niedosytu, uregulowania rangi ustawowej rozstrzygające o miejscu i roli detektywa. Ustawa ta, nie stawiając wystarczających wymogów dla doboru kandydatów do wykonywania zawodu detektywa, nie chroni w stopniu wystarczającym jego ekskluzywizmu, a tym samym - w jakiejś mierze - jakości oferowanych usług. Diagnoza ta, mimo zawartego w niej pesymizmu, postawiona została i tak - jak się wydaje - nieco na wyrost i jest chyba zbytnio zabarwiona entuzjazmem, $\mathrm{w}$ istocie bowiem można mieć wątpliwości także w zakresie uznania elitarności polskiej detektywistyki. Jeśli wszakże prawdziwe ma być założenie, że o owej elitarności decydować ma szczególna funkcja danej grupy w społeczeństwie, to postawić trzeba od razu pytanie - w kontekście wcześniejszych rozważań - czy nawet i tę elitarność da się wykazać, skoro właściwa ustawa nie przyznaje detektywowi żadnych w zasadzie formalnych uprawnień dla realizacji tej funkcji. Jeśli 
więc owa elitarność, z którą immanentnie powiązany jest etos każdego zawodu, stanowi wartość samą w sobie, to warto przypomnieć, że wartość tę zatracono podczas dokonanej w roku 2013 deregulacji, kiedy to - eksponując względy wolności gospodarczej - zredukowano wymogi w zakresie uzyskania dostępu do zawodu detektywa, co przyniosło wprawdzie korzyść w postaci zwiększenia konkurencji wolnorynkowej, wespół z tym doszło jednak do obniżenia jakości usług detektywistycznych, choć - wbrew prognozom - nie towarzyszył temu - widoczny co najmniej - spadek ich cen, nie osiągnięto przy tym węzłowych celów tejże deregulacji, przynajmniej tych deklarowanych oficjalnie. Zwiększyła się przy tym liczba nieprawidłowości wśród przedstawicieli zawodu w obszarze etycznych jego aspektów. Mimo wszystko polska detektywistyka zdaje się zajmować szczególną i wyróżniającą się pozycję pośród innych porównywalnych państw europejskich. Szanse stąd płynące zostały dostrzeżone przez Polskie Stowarzyszenie Licencjonowanych Detektywów, które zdaje się nie ustawać w swych staraniach o stałe podnoszenie nie tylko jakości świadczonych usług, lecz także budowanie nowych standardów w wymiarze etycznym, czego najlepszym dowodem jest przyjęty przez jego władze Kodeks Etyki Detektywa. Wyrazem tych starań stało się także przyjęcie Polskiego Stowarzyszenia Licencjonowanych Detektywów w poczet członków Internationale Kommission der Detektiv-Verbände, gdzie polskie Stowarzyszenie nie tylko zdobyć może nowe doświadczenia, lecz także wnieść twórczy wkład w rozwój detektywistyki europejskiej, stając się przy tym jej liderem.

\section{Bibliografia}

Aleksandrowicz T.R. (red.), Komentarz do ustawy o ustugach detektywistycznych, Warszawa 2002.

Aleksandrowicz T.R., Konieczny J., Konik A., Podstawy detektywistyki. Ustugi detektywistyczne, prawo, taktyka, moralność, Warszawa 2008.

Berent M., Analiza krytyczna ustawy o usługach detektywistycznych w kontekście opracowania projektu nowej regulacji prawnej, http://www.psld.pl/wp-content/uploads/2016/01/

Marcin_Berent_Zjazd_PSLD_Analiza_krytyczna_UoUD.pdf (13.02.2016).

Duby G., Czasy katedr. Sztuka i spoteczeństwo 980-1420, Warszawa 1984.

Gozdór G., Ustugi detektywistyczne, Warszawa 2005.

Hanausek T., Kryminalistyka. Zarys wykładu, Warszawa 2009.

Hołyst B., Kryminalistyka, Warszawa 2007.

Jankowska A., Wolny jak detektyw, „Wprost”, 4.01.2015.

Kasprzak J., Młodziejowski B., Brzęk W., Moszczyński J., Kryminalistyka, Warszawa 2006.

Kędzierska G., Kędzierski W., Kryminalistyka. Wybrane zagadnienia techniki, Szczytno 2011. 
Kulicki M., Kwiatkowska-Wójcikiewicz V., Stępka L., Kryminalistyka. Wybrane zagadnienia teorii i praktyki śledczo-sądowej, Torun 2009.

Ossowska M., Ethos rycerski i jego odmiany, Warszawa 2000.

Sobol E. (red.), Mały słownik jezzyka polskiego, Warszawa 1994.

Tokarczyk R., Etyka prawnicza, Warszawa 2005.

Widacki J. (red.), Kryminalistyka, Warszawa 2012.

Zakrzewski L.S., Ethos rycerski w dawnej i wspótczesnej wojnie, Warszawa 2004. 